\title{
Wizerunek Jana i Karola IV Luksemburgów w Rocznikach Jana Długosza
}

\begin{abstract}
Zarys treści: Artykuł dotyczy wizerunków Jana i Karola IV Luksemburgów nakreślonych przez Jana Długosza w IX i X księdze Roczników. Szczegółowej analizie zostały poddane wszystkie zapisy krakowskiego historiografa w Rocznikach odnoszące się do obu władców. Autor dowodzi, że Długosz charakteryzował postaci Jana i Karola IV oraz ich dokonania z punktu widzenia interesów i racji politycznych Królestwa Polskiego oraz późnośredniowiecznego ideału władcy chrześcijańskiego.
\end{abstract}

\begin{abstract}
The paper deals with the images of John and Charles IV of Luxemburg as presented by Jan Długosz in Books IX and X of his Annals. All fragments in the Annals which the Cracovian historian devoted to both monarch were meticulously analysed. The author argues that Długosz characterised the figures of John and Charles IV and their achievements from the standpoint of the interests and political raison d'État of the Kingdom of Poland and the late medieval ideal of a Christian ruler.
\end{abstract}

Słowa kluczowe: Jan Długosz, Jan Luksemburski, Karol IV Luksemburski, dziejopisarstwo, Królestwo Polskie, wizerunek władcy

Keywords: Jan Długosz, John of Luxemburg, Charles IV of Luxemburg, historiography, Kingdom of Poland, image of the ruler

Jan Długosz kreślił na kartach swych monumentalnych Roczników wizerunki polskich książąt i królów z dynastii Piastów, Andegawenów i Jagiellonów oraz władców z państw środkowej Europy. Na ich czyny i cechy charakteru spoglądał z reguły przez pryzmat późnośredniowiecznego ideału monarchy chrześcijańskiego oraz interesów i racji politycznych Królestwa Polskiego ${ }^{1}$. W dotychczasowej literaturze

${ }^{1}$ Z prac poświęconym wizerunkom władców w Rocznikach Jana Długosza zob. M. K o c zers k a, Mentalność Jana Długosza w świetle jego twórczości, Studia Źródłoznawcze 15, 1970, s. 119-123; Z. P e r z a n o w s k i, Kanonik krakowski ks. Jan Długosz o królowej Jadwidze, Analecta Cracoviensia 12, 1980, s. 193-267; K. B i e drow s k a - O c h m ań s k a, J. O c h m ań s ki, Władysław Jagiełło w opiniach swoich współczesnych. Próba charakterystyki jego osobowości, Poznań 1987, s. 33-77; J. K r z yża n i a k o wa, Eruditio et scientia w Długoszowych wizerunkach władców i biskupów, w: Mente et litteris. O kulturze i społeczeństwie wieków średnich, Poznań 1984, s. 271-275; t a ż, Portret niedokończony. Kazimierz Jagiellończyk w Annales Jana Długosza, w: Ecclesia, cultura, potestas. Studia z dziejów kultury i społeczeństwa, Kraków 2006, s. 487-500; J. S k o m i a 1, Jan 
przedmiotu brak jest systematycznego studium na temat wizerunku obu Luksemburgów w dziele Długosza².

Roczniki powstawały pod piórem Długosza w kilku etapach przez ćwierć wieku, co ma istotne znaczenie dla niniejszych badań nad podanymi przez dziejopisarza informacjami o Janie i Karolu Luksemburgach. Pierwsza redakcja dzieła została ukończona ok. 1466 r. Przez następne kilkanaście lat, aż do śmierci w 1480 r., historiograf ją uzupełniał i poprawiał. Efektem tych prac była druga redakcja. Zakres amplifikacji i zmian był poważny, Długosz dopisał bowiem na marginesach, w wolnych miejscach oraz na nowych, dołączanych kartach bardzo wiele informacji pozyskanych z nowych źródeł. Skorygował również dużo fragmentów z pierwszej redakcji w oparciu o nowe materiały, które uważał za bardziej wiarygodne. Jeszcze w połowie lat siedemdziesiątych XV w. Jan Długosz rozpoczął trzecią redakcję, która objęła jednak tylko część Roczników sięgającą $1338 \mathrm{r}^{3}$

Krakowski historiograf w szczególny sposób interesował się przeszłością Czech i o sprawach czeskich pisał, poczynając od czasów najdawniejszych aż po rok 1480. Informacje o historii państwa czeskiego w dobie Przemyślidów czerpał Jan Długosz głównie z kronik Přibíka Pulkawy z Radenína, Kosmasa, Dalimila i Eneasza Sylwiusza Piccolominiego oraz kronik i roczników polskich ${ }^{4}$. Natomiast panowanie dwóch pierwszych Luksemburgów na tronie praskim Jana i Karola IV opisał w księgach dziewiątej i dziesiątej Roczników, korzystając z rozmaitych źródeł historiograficznych5.

Długosz o Władysławie II Jagielle (Charakterystyka króla w świetle „Annales seu Cronicae incliti Regani Poloniae”), Acta Universitatis Lodziensis. Folia Iuridica 61, 1994, s. 15-31; t e nże, Polski portret litewskiego władcy. Witold Kiejstutowicz w świetle Annales Jana Długosza, w: „Rodzinna Europa”. Europejska myśl polityczno-prawna u progu XXI wieku, Wrocław 2015, s. 41-61; W. S z y m b o r s k i, Władysław Jagiełł: władca idealny czy święty?, w: Sprawiedliwość: tradycja i współczesność, Kraków 2006, s. 53-71; w szerszym kontekście zob. K. O ż ó g, The Concept „rex illiteratus quasi asinus coronatus” in Late Medieval Cracovian Writings, w: Book versus Power. Studies in the Relations between Politics and Culture in Polish History, Frankfurt am Main 2015, s. 73-88; A. Ta la row s k i, Od poganina do króla arcychrześcijańskiego. Wizerunek Władysława Jagiełły w Rocznikach Jana Długosza, Średniowiecze Polskie i Powszechne 9 (13), 2017, s. 127-152.

2 Por. W. D o min i a k, Jak postrzegano Luksemburgów na ziemiach polskich, w: Jan Lucemburský: kultura, umění a zbožnost na Moravě a ve Slezsku v době vladý prvního Lucemburka, Ostrava 2012, s. 30-35; A. F i 1 i p e k - M i s i a k, Karol IV Luksemburski jako ideał władcy w Catalogus abbatum Saganensium, Historie, otazký, problémy 7, 2015, nr 1, s. 76-89; L. B o b k o vá, Jan Lucemburský. Otec slavného syna, Praha 2018, s. 463-472.

3 W. S e m k ow i c z-Z a r e m b in a, Powstanie i dzieje autografu Annalium Jana Długosza, Kraków 1952, s. 6-57; P. D y m m e 1, Uwagi nad historią tekstu w autografie Annales Jana Długosza, w: Venerabiles, nobiles et honesti. Studia z dziejów społeczeństwa Polski średniowiecznej. Prace ofiarowane Profesorowi Januszowi Bieniakowi w siedemdziesiątą rocznicę urodzin i czterdziestolecie pracy naukowej, Toruń 1997, s. 467-476.

${ }^{4}$ S. S o li c k i, Źródła Jana Długosza do problematyki czeskiej, Wrocław 1973, s. 5-124; J. P e t r á s e k, České dějiny ve světle strategie vyprávění Annales Jana Długosze, Mediaevalia historica Bohemica 20, 2017, nr 1, s. 181-206.

5 Ioannis Dlugossii Annales seu cronicae incliti Regni Poloniae, lib. IX, Varsaviae 1978 (dalej cyt.: Annales IX); lib. X, Varsaviae 1985 (dalej cyt.: Annales X); Jana Długosza Roczniki czyli kroniki sławnego Królestwa Polskiego, tłum. J. Mrukówna, ks. IX, Warszawa 1975 (dalej cyt.: Roczniki IX), ks. X, Warszawa 1981 (dalej cyt.: Roczniki X). 
Przede wszystkim Długosz miał w swoich rękach co najmniej dwa rękopisy Chronicon Bohemiae Pulkawy, które posłużyło mu za podstawowe źródło do opisu rządów Jana Luksemburskiego od objęcia tronu praskiego w 1310 do poddania swemu zwierzchnictwu części książąt śląskich w 1327 r. ${ }^{6}$ Pierwszy z tych rękopisów z piątą redakcją Kroniki Pulkawy, zawierający I księgę (do 1307 r.), w nieznanych okolicznościach trafił do rąk Zbigniewa Oleśnickiego, a na mocy jego testamentu w 1455 r. został przekazany do katedry krakowskiej. Obecnie kodeks ten jest przechowywany w Bibliotece XX. Czartoryskich w Krakowie (rękopis 1414). Długosz miał dostęp do tego rękopisu, bowiem na marginesach Kroniki Pulkawy i w jej tekście poczynił własnoręcznie szereg uwag ${ }^{7}$. Natomiast drugi, nieznany nam bliżej rękopis Pulkawy, z którego korzystał krakowski historiograf, mieścił obie księgi tego dzieła z narracją do 1330 r., czyli szóstą redakcję Kroniki. To właśnie ten, niezachowany dziś rękopis, umożliwił Długoszowi ukazanie w Rocznikach pierwszych kilkunastu lat rządów Jana Luksemburskiego w Czechach ${ }^{8}$. Informacje o dalszych latach panowania Jana, a potem jego syna Karola IV, polski historyk czerpał z szeregu utworów historiograficznych polskich i obcych, przede wszystkim z Kroniki Jana z Czarnkowa, Kroniki książąt polskich Piotra z Byczyny, De scismate Teodoryka z Nieheim, Historia Bohemica Eneasza Sylwiusza Piccolominiego, Fasciculus temporum Wernera Rolewincka oraz innych, nieznanych źródeł ${ }^{9}$. Traktat kurialisty rzymskiego i koncyliarysty Teodoryka Nieheim De scismate, powstały w latach 1409-1410, zawierał szczegółowy opis dziejów wielkiej schizmy zachodniej od 1378 r. do soboru w Pizie i początku pontyfikatu Jana XXIII ${ }^{10}$. Długosz zapoznał się z tym dziełem, gdy pracował nad drugą redakcją Roczników, a więc po 1466 r. Być może rękopis De scismate otrzymał za pośrednictwem zaprzyjaźnionego kanonika wrocławskiego Mikołaja Merbotha ${ }^{11}$. Z kolei Eneasz Sylwiusz Piccolomini, którego Długosz znał osobiście, napisał w 1458 r. dzieło o dziejach Czech od legendarnych początków do 1458 r. ${ }^{12}$ Krakowski historiograf czerpał z obficie z tej Historia Bohemica, choć krytycznie się o niej wypowiedział, charakteryzując Eneasza Sylwiusza w relacji o jego wyborze na papieża ${ }^{13}$. W ręce

${ }^{6}$ S. S o li c k i, Źródła, s. 12-28.

${ }^{7}$ Catalogus codicum manu scriptorum Musei Principum Czartoryski Cracoviensis, t. II, opr. S. Kutrzeba, Cracoviae 1908-1913, s. 202-203; S. S o l i c k i, Źródła, s. 14-17; M. B lá h o vá, Přibíka Pulkavy z Radenína Kronika česká, w: Kroniky doby Karla IV, Praha 1987, s. 578.

${ }^{8}$ S. S o 1 i c k i, Źródła, s. 14-15; M. B lá h o vá, Přibíka Pulkavy Kronika, s. 573-577.

9 S. S o li c ki, Źródła, s. 34-46, 50.

${ }_{10}$ Theoderici de Nyem De scismate libri tres, wyd. G. Erler, Lipsiae 1890; J. L e u s c h n e r, Dietrich von Nieheim, w: Die deutsche Literatur des Mittelalters. Verfasserlexikon, t. II, Berlin-New York 1980, kol. 140-144; K. C o 1 b e r g, Dietrich von Nieheim, w: Lexikon des Mittelaters, t. III, München 2003, kol. 1037-1038; Theodericus de Niem, w: Repertorium fontium historiae medii aevi, t. XI, Romae 2006, s. 134-137.

${ }^{11}$ I. Z a rę b s k i, Teoderyk de Niem jako źródło do dziejów polskich (uwagi wstępne), w: Mediaevalia. W 50 rocznicę pracy naukowej Jana Dąbrowskiego, Warszawa 1960, s. 255262; K. S t a c how s k a, Zapożyczenia Jana Długosza z dzieła Teodoryka z Niem, „De scismate", Rocznik Biblioteki PAN w Krakowie 4, 1958, s. 65-112.

12 Aeneae Silvii Historia Bohemica, wyd. D. Martínková, A. Hadravová, J. Matl, Pragae 1998, s. LIII-LXXXV, 1-257.

13 Annales XII (1445-1461), s. 313: Vir parve stature sed magni ingenii, in Almanos propensum favorem gerens, in Polonos parum propicius. Qui in cardinalatus dignitate consistens, 
Długosza kopia Historii trafiła najpewniej po 1464 r., prawdopodobnie za pośrednictwem kanonika wrocławskiego Mikołaja Tempelfelda z Brzegu, byłego profesora teologii Uniwersytetu Krakowskiego i kaznodziei w kościele NMPanny w Krakowie, który dowodnie posiadał to dzieło w 1463 r. ${ }^{14}$ Zwięzły wykład dziejów powszechnych od stworzenia świata do 1474 r., opracowany przez kolońskiego kartuza Wernera Rolewincka, zatytułowany Fasciculus temporum, ukazał się drukiem już w 1474 r. i od razu zyskał wielką popularność ${ }^{15}$. Długosz szybko postarał się o tę kronikę uniwersalną i przejął z niej szereg wiadomości, które włączył do Roczników ${ }^{16}$. Czerpiąc z wymienionych utworów informacje o obu Luksemburgach, modyfikował je wedle własnej koncepcji historiograficznej. Ich wizerunki narastały pod piórem krakowskiego dziejopisarza etapami i były uzupełniane w kolejnych redakcjach Roczników.

Luksemburgowie po raz pierwszy zostali wprowadzeni na karty Roczników pod 1308 r., bowiem pod tą datą Jan Długosz, za nieznanym źródłem, przekazał informację o wyborze „w dzień św. Katarzyny” Henryka hrabiego Luksemburga na króla rzymskiego we Frankfurcie i jego koronacji w Akwizgranie „w święto Epifanii" 1309 r. ${ }^{17}$ Dodał do tego wiadomość o szlachetnym czynie nowego króla, który ciała zamordowanych poprzedników na tronie rzymskim, Adolfa i Albrechta, kazał wydobyć z grobów, gdzie byli pochowani, oraz uroczyście je pogrzebać w nekropolii królewskiej w katedrze w Spirze. Przy okazji relacji o sytuacji w Czechach pod 1311 r. historyk scharakteryzował Henryka krótko, ale bardzo pozytywnie, pisząc że ,z powodu niezwykłych obyczajów, cnót i czynów, którymi górował nad innymi znakomitymi mężami i władcami powołano go zgodnie na tron cesarski po zamordowaniu króla rzymskiego i księcia Austrii Alberta"18. Natomiast przy opisie koronacji cesarskiej oraz śmierci Henryka VII pod 1313 r. dopełnił jego wizerunek, podając że był człowiekiem pobożnym i ,nigdy nie okazywał pychy w czasie powodzenia, nigdy przygnębienia niepowodzeniem" ${ }^{19}$. W poglądach Długosza na wzorowego władcę ważną rolę odgrywały przymioty, którymi obdarzył Henryka VII, tj. czystość obyczajów, stałość w powodzeniach i niepowodzeniach, pokora oraz pobożność ${ }^{20}$. Tak więc ojciec Jana Luksemburskiego cieszył się pozytywną opinią polskiego dziejopisarza, uosabiając nieomal idealnego monarchę chrześcijańskiego.

stilo suo, quo plurimum valuit, corpus historie Bohemice contexens, singula gloriosa et heroica de Polonis in Cronica Bohemorum notata, silencio absolvit, ignominiosa vero et genus Polonorum dedecorancia plus iusto extulit; zob. I. Z a r ę b s k i, Stosunki Eneasza Sylwiusza z Polską i Polakami, Kraków 1939, s. 43-48, 131-150; S. S o li c k i, Źródła, s. 33-38, 112124; R. O j r z y ń s k i, Obraz Polski i Polaków w pismach Eneasza Sylwiusza Piccolominiego (papieża Piusa II), Warszawa 2014, s. 148-153.

14 S. S o 1 i c k i, Źródła, s. 35-36.

15 J. S o s z y ń ski, Dzieje starożytne w Fasciculus temporum Wernera Rolevincka, Z Badań nad Książką i Księgozbiorami Historycznymi 7-8, 2013-2014, s. 15-30; A. W o r m, Rolevinck Werner, w: Encyclopedia of the Medieval Chronicle, t. II, Leiden 2010, kol. 12921294.

16 S. S o 1 i c k i, Źródła, s. 49-50.

${ }^{17}$ Annales IX, s. 53; Roczniki IX, s. 66-67.

18 Annales IX, s. 72; Roczniki IX, s. 89.

19 Annales IX, s. 87-88; Roczniki IX, s. 110.

${ }^{20}$ M. K o c ze r s k a, Mentalność, s. 122-123. 
Za przekazem Pulkawy Jan Długosz przedstawił szerzej okoliczności objęcia tronu czeskiego przez Jana Luksemburskiego i jego koronacji. Relację umieścił pod 1311, ale przywołał w niej również wydarzenia z $1310 \mathrm{r}^{21}$ Historiograf bardzo mocno przy tym podkreślił, że hrabia Luksemburga został ukoronowany na króla Czech w wyniku usilnych zabiegów panów czeskich. Zaraz potem dodał od siebie, że za sprawą tych właśnie panów Jan od swojej koronacji praskiej uważał się nie tylko za króla Czech, ale i Polski, choć „nie miał żadnego prawa do Królestwa Polskiego”, wynikającego z elekcji, powołania na polski tron czy też dziedzictwa ${ }^{22}$. Mimo, że inicjatywę używania przez Jana tytułu króla Polski Długosz przypisał panom czeskim, to sprawa ta będzie mocno rzutować na ocenę polityki Luksemburga wobec Królestwa Polskiego przez kronikarza.

Już u początków panowania Jana w Czechach krakowski historyk nakreślił jego negatywny wizerunek moralny. Po informacji o śmierci i pogrzebie Henryka VII Luksemburskiego w katedrze pizańskiej Jan Długosz tak scharakteryzował króla czeskiego: „Potem jego syn Jan, król Czech, zaczął od tego czasu postępować nieroztropnie, unosić się w pychę i traktować z pogardą panów, magnatów, rycerstwo i szlachtę. Stawiając wyżej od nich każdego Niemca, pomiatając wszystkimi Czechami, oddawał stanowiska i urzędy Szwabom i mieszkańcom Nadrenii, a nie dopuszczał do nich Czechów. Czesi nie mogąc znieść zniewagi, wyrzucają go i wyganiają z królestwa czeskiego - co mu się słusznie należało - zatrzymawszy u siebie w Pradze królową Elżbietę"23. Cały ten fragment poświęcony Janowi Luksemburskiego, oparty na Kronice Jana z Czarnkowa, Długosz włączył pod 1313 r. w drugiej redakcji Roczników ${ }^{24}$. Ostrze krytyki wymierzone zostało w króla Jana z powodu faworyzowania Niemców na dworze i odsuwania od urzędów Czechów. Ponadto głównym grzechem Luksemburga w oczach krakowskiego kronikarza była pycha i traktowanie z pogardą czeskiej elity, co mocniej wyeksponował od Jana z Czarnkowa, który podał tylko, że młody król był „nie tyle waleczny, ile przewrotny” (non tam animosus quam dolosus $)^{25}$. W kontekście poglądów Długosza na ideał monarchy chrześcijańskiego pycha i złe traktowanie poddanych charakteryzowały władcę-tyrana ${ }^{26}$. Konflikty króla

${ }^{21}$ Annales IX, s. 72-73; Roczniki IX, s. 89-91; Kronika Pulkavova, wyd. J. Emler, J. Gebauer, Fontes rerum Bohemicarum, t. V, Praha 1893, s. 196-197; S. S o 1 i c k i, Źródła, s. 105-106. Dla faktografii panowania Jana Luksemburskiego podstawowe znaczenie mają prace: J. Š u s t a, Král cizinec, Praha 1939 (České dějiny, t. II, cz. 2); t e n ż e, Karel IV. Otec a syn 1333-1346, Praha 1946 (České dějiny, t. II, cz. 3); J. Š p ě vá č e k, Král diplomat. Jan Lucemburský 1296-1346, Praha 1982; W. I w a ń c z a k, Jan Luksemburski. Dzieje burzliwego żywota i bohaterskiej śmierci króla Czech i hrabiego Luksemburga w 21 odsłonach, Warszawa 2012; L. B o b k ová, Jan Lucemburský.

${ }_{22}$ Annales IX, s. 73; Roczniki IX, s. 90-91; por. J. Š u s t a, Král cizinec, s. 109-155; J. Š p ě v á č e k, Král dyplomat, s. 60-72; L. B o b k o v á, Jan Lucemburský, s. 42-62, 81-85; B. N o w a cki, Czeskie roszczenia do korony w Polsce w latach 1290-1335, Poznań 1987, s. 74-81; W. I w a ń c z a k, Jan Luksemburski, s. 131 n.

${ }^{23}$ Annales IX, s. 88; Roczniki IX, s. 110.

${ }^{24}$ Biblioteka XX. Czartoryskich, Cod. 1306, s. 750; Kronika Jana z Czarnkowa, wyd. J. Szlachtowski, Monumenta Poloniae historica, t. II, Lwów 1872, s. 686.

${ }^{25}$ Kronika Jan z Czarnkowa, s. 686; Kronika Jana z Czarnkowa, tłum. J. Żerbiłło, opr. M.D. Kowalski, Kraków 2009, s. 77.

${ }^{26}$ M. K o c z e r s k a, Mentalność, s. 122-123. 
z czeską szlachtą miały, według błędnego mniemania Długosza, doprowadzić nawet do czasowego usunięcia władcy z tronu. Opowiadanie o konfliktach Jana z czeskimi poddanymi i domniemanych próbach odzyskania przezeń władzy w Czechach rozwijał historyk w paru odsłonach pod rokiem 1317 i 1319. Za nieznanym źródłem ukazał pod 1317 r. zwycięstwo Viléma Zajíca z Valdeka nad Luksemburgiem, podkreślając, że Janowi nie udało się wtedy odzyskać tronu ${ }^{27}$. Dodał przy tym w drugiej redakcji Roczników, że władca ten wyrządził wiele krzywd Królestwu Czeskiemu i został znienawidzony przez wszystkich nieomal Czechów, zaś panowie czescy żałowali, że „wybrali na króla czeskiego człowieka pochodzenia niemieckiego, z natury nieżyczliwego im i ich językowi słowiańskiemu i ohydnych obyczajów"28. Natomiast zakończenie konfliktu Jana Luksemburskiego z czeskimi poddanymi umieścił Długosz pod 1319 r. i opisał domniemany powrót króla z wygnania. Przy tej okazji rozszerzył charakterystykę władcy. Najpierw zaznaczył, że Jan jako ,z natury podstępny i przebiegły" zaniechał walki zbrojnej o odzyskanie tronu i doprowadził do zawarcia porozumienia z Czechami. Pod przysięgą miał obiecać poddanym, że ,poprawi swoje obyczaje i postępowanie"29. Odzyskawszy tron chciał jednak zemścić się ukradkiem na Czechach. Podstępne działania władcy Długosz opisał następująco: „,[król] otacza murem bardzo przyjemną łąkę, naokoło niej buduje wieże i ogłasza Czechom turnieje, zamierzając w czasie walki wymordować rękoma rycerzy niemieckich, zajętych walką panów i baronów czeskich, którzy potajemnie mieli być zamknięci w tych wieżach. Kiedy królowa czeska Elżbieta przeczuła ten nieszczęsny podstęp, pragnąc odwrócić tak godną współczucia rzeź swego narodu, donosi panom czeskim, jakie zło zgotowano na ich głowy. A ci zebrawszy pospiesznie oddziały, gromadzą się z wojskiem w pobliżu łąki, gdzie miały się odbyć turnieje i burzą doszczętnie do fundamentów zarówno biegnący mur, jak i zbudowane wielkim kosztem na ich zgubę wieże. Wstrząśnięty tą nowiną król Jan, bojąc się, żeby kiedyś jego podstępne knowania nie spadły na jego głowę, nie podejmował już więcej zgubnych knowań i napadów na Czechów" "30. Tę barwną opowieść zaczerpnął krakowski historiograf z Kroniki Jana z Czarnkowa (modyfikując w niektórych szczegółach) jako swego rodzaju exemplum ilustrujące niegodziwość i podstępny charakter Jana Luksemburskiego $^{31}$. Pobrzmiewają w nim echa biblijne, bowiem królowa Elżbieta podobnie jak Estera ratuje swój naród od zagłady ${ }^{32}$. W świetle powyższej historii za szczególnie naganne w postępowaniu Luksemburga uznawał Długosz podstępne dążenie do wymordowania elity szlachty czeskiej oraz złamanie przysięgi danej poddanym. W wizerunku tego monarchy krakowski dziejopisarz coraz mocniej podkreślał negatywne cechy i uznawał go za coraz bardziej niegodziwego władcę ${ }^{33}$.

${ }^{27}$ Annales IX, s. 97-98, 105-106; Roczniki IX, s. 121, 129-130; por. J. Š u s t a, Král cizinec, s. 225-311; J. Š pě vá č e k, Král dyplomat, s. 96-127; W. I w a ń c z a k, Jan Luksemburski,

s. 72-81; L. B o b k o vá, Jan Lucemburský, s. 97-114.

${ }^{28}$ Biblioteka XX. Czartoryskich, Cod. 1306, s. 756; Annales IX, s. 98; Roczniki IX, s. 121.

${ }^{29}$ Annales IX, s. 105; Roczniki IX, s. 130.

${ }^{30}$ Annales IX, s. 105-106; Roczniki IX, s. 130.

${ }^{31}$ Kronika Jana z Czarnkowa, s. 687.

${ }^{32}$ Księga Estery 3-8.

${ }^{33}$ Por. M. K o c z e r s k a, Mentalność, s. 122-123. 
Zwięźle natomiast historiograf skomentował pod 1319 r. przeciwdziałanie posłów Luksemburga w Awinionie wobec starań o koronę królewską dla Władysława Łokietka u papieża Jana XXII. Stwierdził, że między biskupem włocławskim Gerwardem, posłem Łokietka, a dyplomatami króla czeskiego trwał przed Stolicą Apostolską spór o prawa obu władców do Królestwa Polskiego. W tej sytuacji papież, nie chcąc narazić się Janowi Luksemburskiemu, jako że był on spokrewniony z królem Francji, powstrzymał się od jednoznacznego przyznana korony dla księcia Władysława Łokietka, choć zgodził się warunkowo na jego koronację ${ }^{34}$. Przy tej okazji Długosz wspomniał, że Jan ożenił swego syna Wacława z córką Filipa króla francuskiego i wysłał go na wychowanie na dwór francuski, gdzie Wacław otrzymał imię Karola. Dziejopisarz pomylił imię ojca Blanki Małgorzaty, pierwszej żony Karola IV, był nim bowiem brat króla francuskiego Filipa IV Pięknego, Karol I de Valois ${ }^{35}$.

Stosunki króla czeskiego z książętami śląskimi stały się dla Długosza okazją, aby powrócić do wątku o niegodziwej polityce Jana Luksemburskiego. Pod 1322 r. umieścił w Rocznikach obszerniejszą relację o uzależnianiu książąt śląskich przez czeskiego władcę. Korzystał przy tym z Kroniki Jana z Czarnkowa ${ }^{36}$. Podkreślił najpierw, że król Jan, poznawszy swoich śląskich sąsiadów, postanowił narzucić im zwierzchnictwo, a następnie realizował ten plan, posługując się przekupstwem i darami wobec książąt piastowskich. Ponadto wzniecał między nimi spory i wojny, a także wspierał raubritterów, aby napadali i łupili sąsiednie księstwa. Tymi sposobami chciał niejako przymusić śląskich Piastów do oddania się pod jego opiekę i złożenia mu hołdów lennych. Według Długosza cała polityka Jana Luksemburskiego wobec książąt polskich dowodziła jego „,przewrotnego charakteru”37. Ze szczególnym potępieniem polskiego historiografa spotkał się układ z 1327 r. między księciem wrocławskim Henrykiem VI a Janem Luksemburskim w sprawie zapisu księstwa wrocławskiego na rzecz króla czeskiego. Długosz nazwał ten układ zbrodniczym i niegodziwym, bowiem miał on pogwałcić zarówno prawa Boskie, jak i ludzkie, zaś stało się to „z krzywdą Królestwa Polskiego, do którego całości należały zawsze księstwo wrocławskie i miasto Wrocław"38. Do sprawy zhołdowania książąt śląskich przez Jana Luksemburskiego Długosz wrócił, zgodnie z chronologią, pod 1327 r., tym razem winą za oderwanie księstw śląskich z wyjątkiem świdnickiego obarczył również samych książąt piastowskich ze Śląska, którzy z powodu nienawiści do króla Władysława Łokietka i obawy uzależnienia od Królestwa Polskiego poddali

34 Annales IX, s. 101-102; Roczniki IX, s. 125-126; J. Š u s ta, Král cizinec, s. 424-429.

${ }_{35}$ Annales IX, s. 101-102; Roczniki IX, s. 125-126; M. B lá h o vá, Čtyři ženy Karla IV, w: Lucemburkové. Česká koruna uprostřed Evropy, Praha 2012, s. 166-167.

${ }^{36}$ Annales IX, s. 121-125; Roczniki IX, s. 149-155; Kronika Jana z Czarnkowa, s. 688; A. S e m k o w i c z, Krytyczny rozbiór Dziejów polskich Jana Długosza do roku 1384, Kraków 1887, s. 342. O sytuacji na Śląsku w latach 1321-1323 zob. J. D ą b r o w s ki, Dzieje polityczne Śląska w latach 1290-1402, w: Historia Śląska od najdawniejszych czasów do roku 1400, t. I, Kraków 1933, s. 356-364.

37 Annales IX, s. 121; Roczniki IX, s. 150; por. W. I w a ń c z a k, Polityka Luksemburgów wobec Śląska, w: Silesia - Polonia - Europa. Studia dedykowane Profesorowi Idziemu Panicowi, Katowice - Bielsko-Biała 2019, s. 179 n.

${ }^{38}$ Annales IX, s. 123; Roczniki IX, s. 152; J. D ą b r o w s k i, Dzieje polityczne, s. 375-380. 
się zwierzchnictwu króla Czech ${ }^{39}$. Z wielkim oburzeniem zrelacjonował krakowski dziejopisarz pod 1329 r. sprzedaż przez Jana Luksemburskiego jako króla polskiego praw do Pomorza Gdańskiego Zakonowi Krzyżackiemu. Uznał, że Luksemburg uczynił to „powodowany przeklętą żądzą złota i zawiścią, którą płonął wobec króla polskiego Władysława" ${ }^{40}$. Dla podkreślenia, że akt sprzedaży praw do Pomorza z 12 III 1329 r. był bezprawny, przytoczył w drugiej redakcji Roczników w całości jego treśćc ${ }^{41}$.

W bardziej spokojnym tonie Długosz opisał zmagania wojenne Polaków z Janem Luksemburskim w 1331 r., kiedy to jako sojusznik Zakonu Krzyżackiego uderzył on na Wielkopolskę na początku października ${ }^{42}$. Natomiast w relacji o sądzie polubownym w sporze polsko-krzyżackim w $1335 \mathrm{r}$. w Wyszehradzie negatywnie ocenił Jana Luksemburskiego jako arbitra (drugim sędzią był Karol Robert król węgierski). Długosz zarzucił królowi czeskiemu, że był on raczej obrońcą Zakonu Krzyżackiego niż sędzią polubownym, a ponadto został przekupiony darami i złotem. Dlatego „chytrymi wywodami” bronił strony krzyżackiej, a szczególnie praw Zakonu do Pomorza ${ }^{43}$.

Konflikt o zamek w Miliczu, należący do biskupstwa wrocławskiego, a zajęty podstępnie przez Jana Luksemburskiego w 1339 r., Długosz przedstawił dokładnie za Kroniką książąt polskich Piotra z Byczyny, ale pod 1337 r. ${ }^{44}$ Króla czeskiego jako grabieżcę dóbr kościelnych, nieugiętego wobec starań o zwrot zamku podejmowanych przez biskupa wrocławskiego Nankera, krakowski historiograf określił mianem tyrana, choć Piotr z Byczyny nie nazwał tak Luksemburga w całej relacji ${ }^{45}$. Z obawy przed działaniami króla-tyrana tylko czterech kanoników kapituły wrocławskiej odważyło się towarzyszyć biskupowi Nankerowi w ostatniej próbie nakłonienia Luksemburga do oddania Milicza. Wobec nieugiętej postawy władcy biskup obłożył Jana i jego doradców ekskomuniką. Długosz przytoczył za Piotrem z Byczyny w barwniejszej

${ }^{39}$ Annales IX, s. 135-137; Roczniki IX, s. 168-170; J. Š u s t a, Král cizinec, s. 431-441; J. D ą b r o w s k i, Dzieje polityczne, s. 371-380; L. B o b k o v á, Jan Lucemburský, s. 306310; W. I w a ń c z a k, Polityka Luksemburgów, s. 180-181.

${ }^{40}$ Annales IX, s. 141; Roczniki IX, s. 175.

${ }^{41}$ Biblioteka XX. Czartoryskich, Cod. 1306, s. 783-784; Annales IX, s. 141-144; Roczniki IX, s. 176-179; Preussisches Urkundenbuch, t. II, wyd. M. Hein, E. Maschke, Königsberg 1939, nr 639; L. B o b k o vá, Jan Lucemburský, s. 203-204.

${ }^{42}$ Annales IX, s. 172; Roczniki IX, s. 214; L. B o b k o vá, Jan Lucemburský, s. 205, 311-313.

${ }^{43}$ Annales IX, s. 185; Roczniki IX, s. 231; por. S. S z c z u r, Zjazd wyszehradzki z 1335 roku, Studia Historyczne 35, 1992, s. 3-17; L. B o b k o v á, Jan Lucemburský, s. 208-214.

${ }_{44}$ Annales IX, s. 194-197; Roczniki IX, s. 243-247; Kronika książąt polskich, wyd. Z. Węclewski, Monumenta Poloniae historica, t. III, Lwów 1878, s. 518-522; J. D ą b r o w s k i, Dzieje polityczne, s. 436-441; J. M a n d z i u k, Historia Kościoła katolickiego na Śląsku. Średniowiecze, t. I, cz. 2, Warszawa 2004, s. 39-40; L. B o b k o vá, Jan Lucemburský, s. 319-322.

${ }^{45}$ Annales IX, s. 195: Quos dum videret Nankerus episcopus ad irritum recidere, prelatis canonicisque suis mandat, ut secum una ad regem transeant, personaliter illum, si castrum non reddiderit excomunicari. Sed fere omnibus illum timore tiranni deserentibus verentibusque, ne in se gravius quicquam consuleret, cum quatuor tantummodo, quorum Deus perseverancie vigore firmaverat corda - - canonicis Wratislauiensibus, ad monasterium Minorum sancti Iacobi regem in stubella parva refectorio proxima se continentem intrepide accessit; por. Kronika książąt polskich, s. 518-522. 
formie literackiej dialogi między monarchą a biskupem, a następnie między Nankerem a rajcami wrocławskimi, kiedy to ordynariusz nazwał Luksemburga nie królem, lecz królikiem ${ }^{46}$, a to dlatego, że w Królestwie Czeskim nie było metropolity i władca czeski musiał być ukoronowany przez obcego arcybiskupa ${ }^{47}$. Cała opowieść o tym konflikcie posłużyła polskiemu dziejopisarzowi dla pogłębienia negatywnego wizerunku króla czeskiego. Długosz zdecydowanie stał po stronie biskupa Nankera i jako obrońca praw oraz dóbr Kościoła uważał Jana Luksemburskiego za tyrana, prześladowcę Kościoła, grabieżcę jego dóbr, dopuszczającego się niesprawiedliwości, a także nieposłusznego wobec autorytetu władzy ordynariusza wrocławskiego, a nadto słownie obrażającego biskupa ${ }^{48}$. W nocie o śmierci biskupa pod $1341 \mathrm{r}$. zapisanej w pierwszej redakcji Roczników Długosz nawiązał zwięźle do konfliktu o zamek w Miliczu i podał, że Nanker - ,jak powiadają” (fertur autem) - został potajemnie otruty z rozkazu Luksemburga ${ }^{49}$. Wiadomość tą mógł zaczerpnąć z Kroniki Jana z Czarnkowa, który jednoznacznie stwierdził, że biskup został niegodziwie zgładzony przy pomocy trucizny za sprawą króla czeskiego ${ }^{50}$. Jednak krakowski historiograf zmienił wymowę wersji Jana z Czarnkowa poprzez odwołanie się do krążącej na ten temat pogłoski, a więc niezbyt pewnej informacji. Według wiarygodnego przekazu Kroniki książąt polskich Nanker zmarł 10 IV 1341 (quarto Idus Aprilis anno Domini MCCCXLI) ${ }^{51}$, zaś w dołączonym do niej Katalogu biskupów wrocławskich Piotr z Byczyny zanotował, że biskup Nanker odszedł z tego świata wkrótce po tym, jak w Wielki Piątek (6 IV) boso chodził od kościoła do kościoła. Tak więc przyczyną jego zgonu było najpewniej przeziębienie ${ }^{52}$.

Nie złagodziła tych negatywnych opinii przypisana przez Długosza wyłącznie staraniom Jana Luksemburskiego, z całkowitym pominięciem zabiegów jego syna Karola, zasługa utworzenia kościelnej metropolii w Pradze. W ślad za nieznanym źródłem w drugiej redakcji Roczników pod 1344 r. dodał informacje, że to w wyniku usilnych próśb króla czeskiego papież Klemens VI erygował arcybiskupstwo praskie

${ }^{46}$ Annales IX, s. 196: Sed neque rex vester glorietur se fore regem, cum magis regulus quam rex putandus et existimandus est. Por. Kronika książąt polskich, s. 520.

${ }^{47}$ Annales IX, s. 196-197; Roczniki IX, s. 244-245; Kronika książąt polskich, s. 519-520.

${ }^{48}$ Por. M. K o c zer s k a, Mentalność, s. 119-123.

49 Annales IX, s. 220; Roczniki IX, s. 274-275. Tę samą wersję o przyczynie zgonu wrocławskiego pasterza zaprezentował dziejopisarz w ukończonym w 1468 r. Katalogu biskupów wrocławskich, ale już bez owego fertur (Joannis Dlugossii Opera omnia, t. I, Kraków 1887, s. 467-468). O tym katalogu zob. E. P o tk o w s ki, Wrocławscy Episcopi Romani u Jana Długosza, w: Lux Romana w Europie Środkowej ze szczególnym uwzględnieniem Śląska, Katowice 2001, s. 101-108; W. S z e li ń s k a, Śląsk w piśmiennictwie Jana Długosza, Wrocław 1993, s. 65-68.

${ }^{50}$ Kronika Jana z Czarnkowa, s. 666.

${ }^{51}$ Kronika książąt polskich, s. 522. Taką samą datę śmierci zawiera Kalendarz katedry krakowskiej, wyd. Z. Kozłowska-Budkowa, Monumenta Poloniae historica, series nova, t. V, Warszawa 1978, s. 139; zob. Z. B u d k o w a, Nanker, w: Polski słownik biograficzny, t. XXII (1977), s. 516.

${ }^{52}$ Kronika książąt polskich, s. 549: postea bona sexta feria ex devocione nudis pedibus discurrens per ecclesias, breviter est defunctus, videlicet anno domini MCCCXLI, III idus Aprilis (data dzienna zmylona o jeden dzień). Por. T. S i 1 n i c k i, Biskup Nanker, Warszawa 1953, s. 109 (tu błędna data dzienna śmierci biskupa), 131; Z. B u d k o w a, Nanker, s. 516. 
i biskupstwo litomyskie, które wraz z biskupstwem ołomunieckim stało się sufraganią nowej metropolii, a także wyniósł do godności arcybiskupa Arnošta z Pardubic i przesłał mu z Awinionu paliusz ${ }^{53}$. Krakowski historiograf podał poprawną datę (30 IV 1344) ustanowienia arcybiskupstwa praskiego i wyniesienia Arnošta do godności arcybiskupa oraz erygowania biskupstwa litomyskiego i podporządkowania go wraz z biskupstwem ołomunieckim nowej metropolii, tego dnia bowiem Klemens VI w wyniku zabiegów Karola Luksemburga, wówczas margrabiego morawskiego, wystawił bulle w tych sprawach ${ }^{54}$. Długosz nadmiernie wyeksponował rolę Jana Luksemburskiego, który miał dążyć do zmazania obelgi Nankera, że jest bardziej „królikiem niż królem” i dlatego wystarał się o arcybiskupstwo praskie. Ze źródłami dotyczącymi powstania arcybiskupstwa praskiego dziejopisarz zapoznał się prawdopodobnie w 1471 r. w Pradze przy okazji koronacji Władysława Jagiellończyka na króla Czech, gdy otrzymał od niego propozycję jego objęcia ${ }^{55}$.

Poczynając od 1344 r. Jan Luksemburski występował w Rocznikach z przydomkiem Ślepy (Cecus), a bezpośrednia informacja o ślepocie króla znalazła się pod 1345 r. ${ }^{56}$ Ostatnia jego zbrojna wyprawa na Królestwo Polskie w 1345 r. została przez Długosza obszerniej opisana na podstawie nieznanego źródła ${ }^{57}$. Wśród motywów skłaniających Jana Luksemburskiego ataku na Polskę dziejopisarz podał, obok odzyskania Wschowy przez Kazimierza Wielkiego z rąk książąt żagańskich, lenników czeskich i wierności Bolesława księcia świdnickiego Królestwu Polskiemu, również zawiść i zbrodnicze plany króla czeskiego wobec Polski. Długosz ujął to w następujący sposób: „Podobno bowiem z zawiści wobec Polski żywił tak głęboką chęć jej zniszczenia, że byłoby mu miło umierać i schodzić ze świata, gdyby mu się udało rozbić obóz ze swym wojskiem pod Krakowem, ręką ślepca dotknąć murów miasta Krakowa i spowodować pewne spustoszenie Polski. Ale Bóg, który widzi wszystkie dumne myśli i gwałty i karze je, nie pozwolił mu przeprowadzić jego zbrodniczych zamiarów, jakie sobie zakładał celem zniszczenia Królestwa Polskiego, ale owszem pozwolił królowi polskiemu Kazimierzowi i jego narodowi, dla którego wspomniany król czeski wyrażał pogardę w myślach i czynach, odnieść sławne i wspaniałe zwycięstwo nad Czechami”58. Poniósłszy klęskę w tej wyprawie Jan, „wrócił do Czech smutny i przygnębiony" ${ }^{59}$. Dziejopisarz mocno wyeksponował negatywne cechy Luksemburga w kontekście jego wyprawy na Kraków, przede wszystkim zawiść

${ }^{53}$ Biblioteka XX. Czartoryskich, Cod. 1306, s. 842; Annales IX, s. 234-235; Roczniki IX, s. 294-295; J. Š u s t a, Karel IV. Otec a syn, s. 414-421; W. I w a ń c z a k, Jan Luksemburski, s. 250-254; Z. H l e d í k o v á, Arnošt z Pardubic. Arcibiskup, zakladatel, rádce, Praha 2008, s. 35-49; L. B o b k o vá, Jan Lucemburský, s. 430-432.

${ }^{54}$ Monumenta Vaticana res gestas Bohemicas illustrantia, t. I, wyd. L. Klicman, Pragae 1903, nr 363-365.

${ }_{55}$ Zob. M. B o b r z y ń s k i, S. S m o 1 k a, Jan Długosz, jego życie i stanowisko w piśmiennictwie, Kraków 1893, s. 136-137.

${ }^{56}$ Annales IX, s. 234, 235, 240, 242, 243; Roczniki IX, s. 294, 296, 301, 302, 305, 307.

${ }^{57}$ Annales IX, s. 235-237; Roczniki IX, s. 296-298; A. S e m k o w i c z, Krytyczny rozbiór, s. 362; J. Š u sta, Karel IV. Otec a syn, s. 440-445; J. D ą b row s k i, Dzieje polityczne, s. $458-464$.

58 Annales IX, s. 236; Roczniki IX, s. 296.

59 Annales IX, s. 237; Roczniki IX, s. 298. 
wobec Królestwa Polskiego, pogardzanie królem Kazimierzem i polskim narodem, zbrodniczy zamiar zniszczenia Polski oraz pychę ${ }^{60}$. W ostatecznym rozrachunku, według Długosza, to Pan Bóg nie dopuścił do spełnienia się grzesznych zamiarów króla Jana wobec Polski i ukarał go w 1345 r. klęską z rąk Polaków, zaś ta stała się przyczyną smutku i przygnębienia Luksemburga ${ }^{61}$.

Długosz do drugiej redakcji Roczników pod 1346 r. wprowadził notę o rycerskiej śmierci króla Jana w bitwie z Anglikami, podnosząc jego odwagę, waleczność i męstwo oraz zapiskę o pochowaniu jego ciała w katedrze w Luksemburgu (w rzeczywistości ciało zostało złożone w opactwie benedyktyńskim w Altmünster pod Luksemburgiem) ${ }^{62}$. Przy tej okazji dziejopis nie pokusił się jednak o całościową charakterystykę osoby Jana Luksemburskiego i jego panowania w Czechach.

Błędnie krakowski historiograf pod rokiem 1376 przypisał Luksemburgowi otrucie biskupa wrocławskiego Przecława z Pogorzeli. Notę tę wciągnął w drugiej redakcji Roczników za Kroniką Jana z Czarnkowa, który odniósł tę informację do śmierci biskupa Nankera, ale w kontekście wiadomości o zgonie Przecława ${ }^{63}$. Ta omyłka wyniknęła zapewne z pospiesznego i niezbyt dokładnego odczytania i skopiowania informacji ze wspomnianej Kroniki. Należy dodać, że w Katalogu biskupów wrocławskich, ukończonym w 1468 r., Długosz za przyczynę śmierci Przecława z Pogorzeli uznał febrę (ex febribus infirmatus, apud Ottmuchow moritur) i podał zmyloną datę dzienną (octavo Kalendas Aprilis zamiast poprawnej octavo Idus Aprilis), którą mógł wyczytać z Kroniki książąt polskich ${ }^{64}$. Wynika z tego, że historiograf nie uzgodnił w obu dziełach zapisów o przyczynie i dacie dziennej śmierci biskupa Przecława.

W sumie Długoszowy wizerunek króla Jana, mocno nasycony negatywnymi ocenami, został nakreślony już w pierwszej redakcji Roczników w kontekście noty o koronacji praskiej Luksemburga (pod 1311), opowieści o próbie wymordowanie czeskiej elity (pod 1319), obszernych zapisów o podporządkowaniu książąt śląskich (pod 1322 i 1327), konflikcie z biskupem wrocławski Nankerem (pod 1337)

${ }^{60}$ Por. M. K o c z e r s k a, Mentalność, s. 119-123.

${ }^{61}$ Tamże, s. 113-114; A. Ta l a r o w s k i, Dzieje w rękach Opatrzności. Elementy historiozofii Jana Długosza i jej uwarunkowania, Roczniki Historyczne 84, 2018, s. 204 n.

${ }^{62}$ Biblioteka XX. Czartoryskich, Cod. 1306, s. 846; Annales IX, s. 242; Roczniki IX, s. 305-306; W. I w a ń c z a k, Jan Luksemburski, s. 294-300, 307-308; L. B o b k o vá, Jan Lucemburský, s. 443-458.

${ }_{63}$ Annales X, s. 47: Wratislaviensis Przeczslaus de Pogorzala episcopus sequtus in Quadragesime medio moritur, cum annis triginta quinque in Wratislaviensi sede utiliter presedisset, et in ecclesia Wratislaviensi in capella mansionariorum sepelitur quem asseritur Iohannes cecus Bohemie rex ob veteres simultates et odia veneno sustulisse. Kronika Jana z Czarnkowa, s. 666: Anno itaque praedicto, circa medium quadragesimae, reverendus pater dominus Przeczslaus episcopus Wratislaviensis, dictus Pogorzala, in bona senectute, plenus bonis operibus, die $n$. debitum naturae persolvit. Iste Przeczslaus mortuo Nankero episcopo Wratislaviensi, per venenum, cooperante Johanne caeco rege Bohemiae, nequiter perempto, qui Nankerus prius episcopus Cracoviensis, per Johannem papam XXII de Cracoviensi ad Wratislaviensem ecclesiam fuerat translatus --, per capitulum Wratislaviense in episcopum Wratislaviensem fuit electus anno domini MCCCXLI die quinta mensis May. O śmierci Przecława zob. T. J u r e k, Rodowód Pogorzelów, Kraków 2005, s. 59.

${ }^{64}$ Joannis Dlugossii Opera omnia, t. I, Kraków 1887, s. 469; Kronika książąt polskich, s. 551. 
i ostatniej wyprawie na Królestwo Polskie (pod 1345). Natomiast w drugiej redakcji dzieła dopełnił ten negatywny wizerunek Jana przytaczając za Janem z Czarnkowa fragment o faworyzowaniu Niemców i odsuwaniu od urzędów Czechów (pod 1313) oraz przypisując mu błędnie otrucie biskupa wrocławskiego Przecława z Pogorzeli (pod 1376). Ponadto w tej redakcji wprowadził jedyne pozytywne w wymowie zapisy o Luksemburgu, dotyczące jego starań o utworzenie arcybiskupstwa praskiego (pod 1344) oraz rycerskiej śmierci w bitwie z Anglikami (pod 1346). Przypisane przez polskiego historiografa Janowi Luksemburskiemu grzechy i wady były liczne, poczynając od pychy poprzez pożądliwość, chciwość, przewrotność, krzywoprzysięstwa, podstępne i zbrodnicze działania, niesprawiedliwość, prześladowanie Kościoła, zawiść, pogardę, a kończąc na tyrańskich rządach. Z pozytywnych cech króla wspomniane zostały jedynie odwaga, męstwo i waleczność. Z Roczników wyłania się więc generalny wizerunek pierwszego Luksemburga na tronie czeskim jako złego władcy stanowiącego swego rodzaju przeciwieństwo wzorowego monarchy chrześcijańskiego w kontekście późnośredniowiecznych ideałów moralnych ${ }^{65}$.

Karola syna Jana Luksemburskiego Długosz wprowadził po raz pierwszy na karty Roczników pod 1319 r., gdy wspomniał - jak była już mowa - o jego pierwszym małżeństwie z córką Filipa króla francuskiego (recte Karola I de Valois, brata Filipa IV), o imieniu chrzestnym (Wacław), wysłaniu przez ojca na dwór francuski na wychowanie oraz nowym imieniu Karol, które otrzymał we Francji ${ }^{66}$. Wiadomości te zaczerpnął niezbyt dokładnie z Kroniki Pulkawy ${ }^{67}$. Następnie dziejopisarz pod 1322 r. przekazał zwięzłe informacje, że Karol jako margrabia Moraw uczestniczył $\mathrm{z}$ woli ojca $\mathrm{w}$ walkach $\mathrm{z}$ Bolesławem księciem ziębickim (błędnie nazwany niemodlińskim) o Ząbkowice (nieudana wyprawa miała miejsce we wrześniu 1335 r. $)^{68}$, a w 1342 r. doprowadził w Nysie, po rozmowach z nowym biskupem wrocławskim Przecławem z Pogorzeli, do „układu na sprawiedliwych warunkach, mocą których zwrócono zagarnięte i niesłusznie przejęte dobra" ${ }^{69}$. Wiadomości o tym pojednaniu się Luksemburgów z biskupem wrocławskim Długosz zaczerpnął z Kroniki książąt

${ }^{65}$ Por. W. B e rg e s, Die Fürstenspiegel des hohen und späten Mittelalters, Leipzig 1938, s. 59-128; M. K o c z e r s k a, Mentalność, s. 119-123; S. S w i e ż a w s k i, U źródeł nowożytnej etyki. Filozofia moralna w Europie w XV wieku, Kraków 1987, s. 211-219; R. A n t o nín, Ideální panovník českého středověku. Kulturně-historická skica z dějin středověkého myšlení, Praha 2013, s. 291-442.

${ }^{66}$ Annales IX, s. 101-102; Roczniki IX, s. 125-126; M. B lá h o v á, Čtyři ženy, s. 166-167; Dla faktografii rządów Karola IV Luksemburskiego w Królestwie Czeskim, Rzeszy i Italii podstawowe znaczenie mają prace: J. Š u s t a, Karel IV. Otec a syn; t e n ż e, Karel IV. Za císařskou koronou 1346-1355, Praha 1948 (České dějiny, t. II, cz. 4); J. Š pě vá č e k, Karel IV. Život a dílo (1316-1378), wyd. 2, Praha 1980; F. S e i b t, Karl IV. Ein Kaiser in Europa 1346-1378, München 1985; F. K a v k a, Vláda Karla IV. za jeho císařství (1355-1378). Země České koruny, rodová, ř́šská a evropská polityka, t. I-II, Praha 1993; L. B o b k o v á, Velké dějiny zemí Koruny české, t. IVa, Praha-Litomyšl 2003.

${ }^{67}$ Annales IX, s. 101-102; Roczniki IX, s. 125-126; Kronika Pulkavova, s. 200.

${ }^{68}$ Annales IX, s. 121-122; Roczniki IX, s. 150; J. D ą b row s k i, Dzieje polityczne, s. 417-419; L. B o b k o v á, Jan Lucemburský, s. 315-316.

${ }^{69}$ Annales IX, s. 224; Roczniki IX, s. 279; J. D ą b r o w s k i, Dzieje polityczne, s. 441-444; T. S i 1 n i c k i, Dzieje i ustrój Kościoła katolickiego na Śląsku do końca w. XIV, wyd. 2, Warszawa 1953, s. 254-258; L. B o b k o vá, Jan Lucemburský, s. 323-324. 
polskich $^{70}$. Za tą kroniką przedstawił też następnie scenę pojednania się miasta Wrocławia z biskupem Przecławem w obecności Karola Luksemburga. Ponadto margrabia morawski obiecał Bolesławowi księciu brzeskiemu i legnickiemu, że dopomoże mu w pojednaniu się z biskupem wrocławskim, ale tej obietnicy nie spełnił i wyjechał z Wrocławia ${ }^{71}$. Tak więc Karol dążył, według Długosza, do sprawiedliwego pojednania z biskupem wrocławskim i naprawienia krzywd wyrządzonych Kościołowi przez ojca.

Pod 1346 r. dziejopisarz zanotował w drugiej redakcji Roczników za nieznanym źródłem wiadomość o wyborze Karola margrabiego Moraw na króla rzymskiego z inicjatywy papieża Klemensa VI, który celem odsunięcia od tronu rzymskiego Ludwika Bawarskiego upoważnił elektorów cesarstwa do tej elekcji ${ }^{72}$. Ponadto Długosz podał błędnie, że papież ten miał ukoronować Luksemburga na króla rzymskiego w Awinionie, aby w ten sposób „go pocieszyć po stracie ojca, który zginął w bitwie z Anglikami" - w istocie koronacja odbyła się 26 listopada tr. w Bonn ${ }^{73}$. Długosz powtórzył również błędną informację, jakoby żona Karola, Blanka, była córką króla francuskiego Filipa ${ }^{74}$, i że ten miał zabiegać u Klemensa VI o koronację zięcia w Awinionie. Kontynuację powyższego fragmentu stanowi nota wciągnięta do drugiej redakcji Roczników pod 1348 r., mówiąca o śmierci Ludwika Bawarskiego, wojnie Karola IV z antykrólem Gunterem ze Schwarzburga i zgonie tego ostatniego. Zwieńczona ona została stwierdzeniem, że „Karol przejął spokojnie cesarstwo, pozyskawszy darami tych z elektorów, o których wiedział, że są mu szczególnie nieżyczliwi" "75. Uspokojenie sytuacji wewnętrznej w cesarstwie oraz umiejętność pozyskiwania darami przez Karola IV swych przeciwników ma w Długoszowej charakterystyce tego władcy pozytywny wydźwięk. Podobnie jest z informacją o praskiej koronacji Karola Luksemburskiego na króla Czech i jego żony Blanki na królową, omyłkowo wprowadzoną pod 1350 r. (zamiast pod 1347 r.), acz z poprawną datą dzienną 2 września, do drugiej redakcji Roczników za nieznanym źródłem ${ }^{76}$. Długosz podkreślił, że Karol został następcą po ojcu w Królestwie Czeskim zarówno na mocy prawa naturalnego, jak i ,za powszechną zgodą i poparciem wszystkich panów i prałatów Królestwa Czeskiego", a ukoronowany i namaszczony na króla czeskiego został w katedrze praskiej przez arcybiskupa Arnošta z Pardubic ${ }^{77}$. W oczach polskiego historiografa akceptacja ze strony całej elity czeskiej dla sukcesji Karola wraz z jego prawem dziedzicznym do tronu oznaczała niepodważalny fundament legitymizujący władzę Luksemburga w Czechach i powszechne jej uznanie przez

${ }^{70}$ Kronika książąt polskich, s. 526-527.

${ }^{71}$ Annales IX, s. 224; Roczniki IX, s. 279-280; Kronika książąt polskich, s. 527;

72 Biblioteka XX. Czartoryskich, Cod. 1306, s. 846; Annales IX, s. 243-244; Roczniki IX, s. 307-308; J. Š u s t a, Karel IV. Otec a syn, s. 454-465, 484-494.

${ }^{73}$ Annales IX, s. 243-244; Roczniki IX, s. 307-308; J. Š u s t a, Karel IV. Za císařskou koronou, s. 13-15.

${ }^{74}$ Zob. wyżej, przyp. 35.

75 Biblioteka XX. Czartoryskich, Cod. 1306, s. 850; Annales IX, s. 253-254; Roczniki IX, s. 320; F. S e i b t, Karl IV. Ein Kaiser in Europa, s. 150-164.

${ }^{76}$ Biblioteka XX. Czartoryskich, Cod. 1306, s. 848; Annales IX, s. 260; Roczniki IX, s. 329.

77 Annales IX, s. 260; Roczniki IX, s. 329; V. Ž ůr e k, Korunovace a český korunovační řád Karla IV., w: Lucemburkové (jak w przyp. 35), s. 203-207. 
poddanych. W kontekście przytoczonej przez Długosza pod 1337 r. przygany biskupa Nankera pod adresem Jana Luksemburskiego, że został ukoronowany przez obcego metropolitę, nie bez znaczenia było wyakcentowanie przez dziejopisarza, że koronacji Karola dokonał pierwszy arcybiskup praski.

Politykę Karola IV wobec książąt śląskich Jan Długosz opisywał w sposób bardziej stonowany niż to było w przypadku Jana Luksemburskiego. Sprawę księstwa świdnickiego kronikarz ukazał pod 1346 r. w oparciu o nieznane źródła. Najpierw podkreślił, że książę Bolesław II, siostrzeniec Kazimierza Wielkiego, zdołał obronić niezależność swego władztwa przed atakiem ze strony Jana Luksemburskiego, który bez powodzenia oblegał Świdnicę (wyprawa miała miejsce w 1345 r.) ${ }^{78}$. Następnie Długosz zaznaczył, że Karol Luksemburski po objęciu tronu czeskiego zmienił politykę wobec księcia świdnickiego, starając się go pozyskać ,,sprytnymi posunięciami i hojnymi darami”79. I dalej kronikarz podał, że Karol „po śmierci swej pierwszej żony, którą miał z Francji, zawiera związki pokrewieństwa z Bolesławem świdnickim i bierze za żonę jego rodzoną siostrzenicę, jedyną córkę księcia jaworskiego Henryka, Annę. Zaraz na wstępie stawia warunek, że po śmierci Bolesława świdnickiego, który był bezdzietny, otrzyma w spadku jako posag zarówno księstwo jaworskie, jak świdnickie" " Jan Długosz zmylił niektóre fakty, bowiem układy małżeńskie Karola IV z Bolkiem świdnickim zostały zawarte we Wiedniu 10 III 1353 r. po śmierci drugiej żony Luksemburga, Anny, córki Rudolfa II palatyna reńskiego, zaś ślub odbył się w Budzie $27 \mathrm{~V}$ tr. ${ }^{81}$ Akt sukcesyjny dla Luksemburga Bolko II wystawił natomiast w Świdnicy 3 VII 1353 r. Na jego mocy księstwo świdnickie miało przypaść Annie i jej potomkom z małżeństwa z Karolem w razie, gdyby książę zmarł bez męskiego dziedzica, ale dopiero po śmierci Agnieszki, żony Bolka, która miała dożywotnio rządzić tym księstwem ${ }^{82}$. Dziejopisarz podkreślił tylko, że książę układem tym wyrządził krzywdę swemu stryjowi Bolesławowi II ziębickiemu i jego synowi Mikołajowi oraz synom tegoż Mikołaja, którzy mieli wszak prawa dziedziczne do księstwa świdnickiego ${ }^{83}$.

Starania dyplomatyczne Karola IV w Stolicy Apostolskiej, aby biskupstwo wrocławskie oderwać od gnieźnieńskiej metropolii kościelnej i podporządkować je arcybiskupstwu praskiemu, wspomniane w Rocznikach pod 1352 r., spotkały się z wyraźnym potępieniem ze strony Długosza, ale oszczędził on Luksemburgowi bezpośrednich osobistych przytyków z tego powodu ${ }^{84}$. Jednak jako obrońca praw

${ }^{78}$ Annales IX, s. 239-240; Roczniki IX, s. 301-302; J. D ą b r o w s k i, Dzieje polityczne, s. $456-458$.

${ }^{79}$ Annales IX, s. 240: Karolus Bohemie rex non bellis sed ingeniis et largicione sibi Boleslaum Swidiniczensem concilians; Roczniki IX, s. 302.

${ }^{80}$ Annales IX, s. 240; Roczniki IX, s. 302.

81 J. D ą b row s k i, Dzieje polityczne, s. 487-494; J. Š p ě v áč e k, Karel IV, s. 233-234; K. J a s i ń s k i, Rodowód Piastów śląskich, wyd. 2, Kraków 2007, s. 329-330; M. B l á h o v á, Čtyři ženy, s. 168-170.

82 J. D ą b r o w s ki, Dzieje polityczne, s. 491-494.

${ }^{83}$ Annales IX, s. 240; Roczniki IX, s. 302.

${ }^{84}$ Annales IX, s. 264-266; Roczniki IX, s. 334-336; T. S i 1 n i c k i, Dzieje i ustrój Kościoła, s. 260-266; L. B o b k o vá, Velké dějiny, t. IVa, s. 274-275; Z. H 1 e d í k o v á, Arnošt z Pardubic, s. 44-46. 
Kościoła polskiego dziejopis podkreślił, że oderwanie biskupstwa wrocławskiego od metropolii gnieźnieńskiej byłoby rzeczą „,wielce niegodziwą i bolesną” i ,z największą krzywdą i uciskiem dla Kościoła gnieźnieńskiego", co można uznać za mocną naganę tych dążeń Karola.

Roztropną i pokojową politykę Karola wobec książąt w Italii z jednej oraz życzliwość miast włoskich względem Luksemburga z drugiej strony zauważył Jan Długosz W nocie o jego koronacji cesarskiej pod 1355 r., włączonej za nieznanym źródłem do Roczników w drugiej redakcji ${ }^{85}$. Wszystkie szczegóły dotyczące tej koronacji zostały precyzyjnie przekazane przez kronikarza, który podał również informację o ukoronowaniu Anny świdnickiej na cesarzową (określał ją mylnie jako drugą żonę Karola), wzmiankując, że była ona córką księcia jaworskiego Henryka i siostrzenicą księcia świdnickiego Bolesława. Przy tej okazji dodał też, że była ona matką Wacława, urodzonego 23 (recte 26) II 1361 r. w Norymberdze ${ }^{86}$. W zakończeniu relacji o wyprawie Karola do Italii po koronę cesarską historiograf zaznaczył niezbyt dokładnie, że po powrocie do Czech doprowadził do ukoronowania na króla czeskiego czteroletniego Wacława. Ta koronacja nastąpiła dopiero 15 VII 1363 r., zaś Wacław miał wtedy dwa lata ${ }^{87}$. Tak więc w szczegółach genealogicznych występują w opisie Długoszowym pewne błędy. Pozytywny obraz Karola IV, jako władcy pokojowego, roztropnego, cieszącego się życzliwością poddanych, został nieco osłabiony wiadomością, że Luksemburg ,przejeżdżając przez wiele miast, wyłudzał od nich zarówno podatek należny cesarzowi, jak dary i zgromadził dość duży skarb"88.

Krótką informację o założeniu przez Karola IV uniwersytetu w Pradze i zatwierdzeniu fundacji przez papieża Innocentego VI wpisał Długosz pod 1361 r. do Roczników w drugiej redakcji, korzystając ze zwięzłej zapiski w Fasciculus temporum Wernera Rolewincka ${ }^{89}$. Zaraz potem umieścił obszerniejszą notę o fundacji uniwersytetu w Krakowie przez Kazimierza Wielkiego, którą też, zgodnie z wydedukowanymi z różnych źródeł informacjami, związał z 1361 r., nie znał bowiem królewskiego dyplomu fundacyjnego z 12 V 1364 r. oraz papieskiej bulli erekcyjnej z 1 IX tr. ${ }^{90} \mathrm{~W}$ świetle ustaleń Macieja Zdanka dziejopisarz datę fundacji praskiej

${ }^{85}$ Biblioteka XX. Czartoryskich, Cod. 1306, s. 862; Annales IX, s. 273; Roczniki IX, s. 345-346; L. B o b k o vá, Velké dějiny, t. IVa, s. 290-305; K. K u b í n o vá, Imitatio Romae. Karel IV. a Rím, Praha 2006, s. 107-137.

${ }^{86}$ Annales IX, s. 273; Roczniki IX, s. 346; M. B lá h o v á, Čtyři ženy, s. 171-172.

87 J. Š p ě vá č e k, Václav IV. 1361-1419. K předpokladům husitské revoluce, Praha 1986, s. 23 n.

${ }^{88}$ Annales IX, s. 273; Roczniki IX, s. 346. O wielkich sumach pieniędzy podarowanych Karolowi przez bogate miasta włoskie, m. in. Mediolan i Florencję, w trakcie wyprawy do Rzymu w 1355 r. zob. J. Š u s t a, Karel IV. Za císařskou koronou, s. 366-378.

${ }^{89}$ Biblioteka XX. Czartoryskich, Cod. 1306, s. 880; Annales IX, s. 306; Roczniki IX, s. 386; Werner Rolewinck, Fasciculus temporum omnes antiquorum cronicas complectens, w: Rerum Germanicarum scriptores, t. II, wyd. 3, wyd. B. G. Struve, Ratisbonae 1726, s. 565; por. M. S v a t o š, The Studium Generale 1347/48-1419, w: A History of Charles University, Prague 2001, s. 25-36.

${ }^{90}$ Biblioteka XX. Czartoryskich, Cod. 1306, s. 880; Annales IX, s. 307; Roczniki IX, s. 386-387; M. Z d a n e k, O źródłach Jana Długosza do dziejów fundacji Uniwersytetu Krakowskiego, w: Jan Długosz (1415-1480). Życie i dzieła, Kraków 2016, s. 131-139. 
wszechnicy wykoncypował z przekazu Rolewincka, który umieścił tę informację pod pontyfikatem Innocentego VI i celowo powiązał z notą o założeniu uniwersytetu przez Kazimierza Wielkiego w Krakowie. W ten sposób podkreślił fakt równoczesnego powstania obu uniwersytetów ${ }^{91}$. Wedle tej chronologii krakowski historiograf policzył ponadto, że uniwersytet praski funkcjonował zaledwie pięćdziesiąt lat, gdyż zniszczyła go herezja husycka ${ }^{92}$.

W drugiej redakcji pod 1362 r. Długosz za nieznanym źródłem umieścił notę o śmierci Anny świdnickiej, żony Karola IV (bez daty dziennej). Podał przy tym dwie błędne informacje, że Anna była drugą (zamiast poprawnie trzecią) małżonką cesarza, oraz że jego trzecią żoną została Mecellina ex sanguine Bawarorum, która w rzeczywistości nie istniała ${ }^{93}$. Ponadto w tej nocie przekazał wiadomość, że Karol ożenił swego syna Wacława z Joanną, córką Albrechta księcia bawarskiego (na Straubingu), hrabiego Holandii i Hainaut oraz Małgorzaty córki księcia brzeskiego Ludwika, co nastąpiło nie w 1362 r., lecz 29 IX 1370 r. ${ }^{94}$ Natomiast kolejna informacja genealogiczna, że z woli cesarza jego stryj Sobiesław ożenił się z siostrzenicą lub bratanicą (neptis) palatyna reńskiego Ruprechta Rudego (Rufus), nie zasługuje na wiarę ${ }^{95}$. Jan Sobiesław (1355/57 - ok. 1381) był bowiem synem Jana Henryka Luksemburskiego, a więc bratankiem Karola IV, który przez urodzeniem syna Wacława IV planował jego małżeństwo ze swoją córką Elżbietą, zrodzoną z Anny świdnickiej. Brak natomiast jakichkolwiek przekazów źródłowych o domniemanym małżeństwie Jana Sobiesława z krewną Ruprechta ${ }^{96}$. W podsumowaniu tych wiadomości Długosz podkreślił, że przez małżeństwa z domem bawarskim udało się Karolowi pozyskać wrogą dotąd dynastię, która stała się przyjazna w stosunku do Luksemburgów. W ten sposób polski historiograf wyraził podziw dla polityki małżeńskiej cesarza i jego dążeń do pokoju z bawarskimi Wittelsbachami.

Stosunkowo bogaty materiał do wizerunku Karola IV przynoszą relacje pod 1363 r. o wielkim konflikcie andegaweńsko-luksemburskim o cześć królowej Elżbiety Łokietkówny oraz o ślubie Karola IV z Elżbietą pomorską i zjeździe monarchów w Krakowie. Już w pierwszej redakcji Roczników za nieznanym źródłem Jan Długosz umieścił pod tą datą obszerną wiadomość o poselstwie króla węgierskiego Ludwika Wielkiego do cesarza Karola IV w sprawie załagodzenia istniejących sporów ${ }^{97}$. W czasie audiencji posłów węgierskich u cesarza doszło do dyplomatycznego

${ }^{91}$ M. Z d a n e k, O źródłach, s. 134-135.

${ }_{92}$ Annales IX, s. 306; Roczniki IX, s. 386.

${ }^{93}$ Biblioteka XX. Czartoryskich, Cod. 1306, s. 883; Annales IX, s. 313; Roczniki IX, s. 395; K. J a s i ń s k i, Rodowód, s. 329-330; M. B lá h o vá, Čtyři ženy, s. 170-173.

${ }_{94}$ J. Š p ě vá č e k, Karel IV, s. 429-430; K. J a s iń s k i, Rodowód, s. 185-187.

${ }^{95}$ Annales IX, s. 313: Patruo vero Sobeslao marchioni Moravie neptem Roberti Ruffi comitis pallatini Bawarie desponsat; Roczniki IX, s. 395.

${ }^{96}$ O. S c h m i d t, Jan z Moravy, patriarcha aquilejský (†1394) a Jan Soběslav, markrabě moravský (†cca 1381). Př́ispěvek k poznání genealogických vztahů lucemburské sekundogenitury, Časopis Matice moravské 132, 2013, nr 1, s. 25-41.

${ }^{97}$ Biblioteka XX. Czartoryskich, Cod. 1306, s. 884-886; Annales IX, s. 313-318; Roczniki IX, s. 396-401; J. D ą b r o w s k i, Elżbieta Łokietkówna 1305-1380, wyd. 2, Kraków 2007, s. 68-74; R. G r o d e c k i, Kongres krakowski w roku 1364, wyd. 2, Kraków 1995, s. 71-84; F. K a v k a, Vláda, t. I, s. 189 n.; Z. K o r n e k, Wojna o cześć kobiety? Konflikt luksembur- 
skandalu, bowiem Karol uniesiony gniewem z powodu żądań Węgrów matrem Ludowici Hungarie regis parum pudicam asserendo protulerat ${ }^{98}$. Posłowie natychmiast zareagowali na tę obrazę królowej matki, a tym samym Ludwika, wyzywając Karola na pojedynek w obronie honoru obojga. Według Długosza cesarz, dręczony wyrzutami sumienia i napomnieniami swych doradców duchownych i świeckich, zaczął dążyć do załagodzenia całej sytuacji. Dlatego pojednawczo przemówił do posłów, próbując ich przekonać, że obraźliwe słowa pod adresem królowej Elżbiety wypowiedział żartem, a nie serio. Jednakże Węgrzy nie przyjęli tego wyjaśnienia i zdali sprawę z przebiegu misji dyplomatycznej Ludwikowi, który dla pomsty tych krzywd wypowiedział wojnę Karolowi. Następnie historiograf opisał intensywne przygotowania militarne i dyplomatyczne obu stron, powstanie dwóch wrogich koalicji państw, jednej wspierającej Andegawena, a drugiej idącej z pomocą Luksemburgowi. Wskutek mediacji legata Stolicy Apostolskiej doszło jednak do porozumienia, które miało zostać przypieczętowane małżeństwem owdowiałego cesarza z wnuczką króla polskiego Elżbietą, córką księcia słupskiego Bogusława, a krewną Ludwika Wielkiego. W tej relacji Długosz podkreślił, że Karol chciał uniknąć niesprawiedliwej wojny, dlatego gotów był na ustępstwa celem zawarcia pokoju i obiecał słuszne zadośćuczynienie stronie andegaweńskiej ${ }^{99}$. Dziejopisarz wydobył w tej historii negatywne i pozytywne cechy cesarza. Wśród tych pierwszych są gniew i słowna obraza oraz obracanie w żart obraźliwych słów, natomiast z pozytywnych cech zauważyć należy gotowość do ustępstw na rzecz przywrócenia pokoju i zadośćuczynienie za obrazę.

Ślub Karola IV z Elżbietą pomorską w Krakowie 21 V 1363 Jan Długosz połączył z krakowskim zjazdem monarchów we wrześniu 1364 r. w jedno wielkie wydarzenie umieszczone pod 1363 r. ${ }^{100} \mathrm{~W}$ obszernym jego opisie cesarz jawi się pod piórem kronikarza jako jeden z głównych bohaterów. Według Długosza na powitanie przybywającego do Krakowa Karola wyszli wszyscy władcy zgromadzeni już u boku Kazimierza Wielkiego jako gospodarza uroczystości. Byli to, zdaniem kronikarza, Ludwik król węgierski, Zygmunt (!) król duński, Piotr król Cypru i liczni książęta. Cesarz i witający go monarchowie zsiedli z koni i pieszo zbliżyli się do siebie, a potem uściskali sobie prawice oraz wymienili pocałunki. Zaślubiny Karola z Elżbietą odbyły się w katedrze krakowskiej, zaś Kazimierz Wielki wyprawił wielodniowe wesele $\mathrm{z}$ ucztami i turniejami rycerskimi. Jedną z najwspanialszych uczt urządził również rajca krakowski Wierzynek. Spotkanie monarchów zakończyło się „układem o wieczystym pokoju” zawartym i zaprzysiężonym przez wszystkich zgromadzonych w Krakowie władców ${ }^{101}$. W zakończeniu relacji dziejopisarz dodał, że „,cesarz rzymski i król czeski Karol, wyrażając większe od innych podziękowanie

sko-andegaweński 1361-1364, Studenckie Zeszyty Historyczne Koła Naukowego Historyków Studentów Uniwersytetu Jagiellońskiego 19, 2013, s. 7-33.

${ }_{98}$ Annales IX, s. 314; Roczniki IX, s. 396.

99 Annales IX, s. 314-318; Roczniki IX, s. 396-401

100 Annales IX, s. 318-321; Roczniki IX, s. 401-405; R. Gro d e c ki, Kongres, s. 9-14, 55-68, 81-96; S. S z c z u r, Krakowski zjazd monarchów w 1364 roku, Roczniki Historyczne 64, 1998, s. 35-58; J. Š p ě vá č e k, Karel IV, s. 254-255; M. B lá h o v á, Čtyři ženy, s. 172.

${ }_{101}$ Annales IX, s. 321: Diebus autem convivii--peractis, firmata inter se reges et principes amicicia, et icto perpetue pacis federe sacramenti iuramento confirmato; Roczniki IX, s. 405. 
za sławną żonę i hojny posag, wieloma prośbami zobowiązuje usilnie króla polskiego Kazimierza, aby kiedyś raczył przybyć do niego, do Pragi, by odwiedzić wnuczkę i potomstwo, które się z niej narodzi"102. W powyższym opisie wydarzeń krakowskich zauważalna jest nuta sympatii ze strony kronikarza względem cesarza, bowiem Karol nie wywyższa się wobec Kazimierza Wielkiego i pozostałych władców, okazuje wdzięczność królowi polskiemu i za jego gościnność odpowiada zaproszeniem do Pragi, a przede wszystkim dąży do umocnienia pokoju między chrześcijańskimi państwami. Pokojowy charakter cesarza podkreślał Długosz szereg razy na kartach Roczników, ukazując np. Karola jako tego, który doprowadził do zażegnania kilku konfliktów wśród książąt śląskich, a także podejmował próby zaprowadzenia pokoju w Italii ${ }^{103}$.

Ostatnie dłuższe noty o Karolu zapisał Jan Długosz w księdze dziesiątej Roczników pod latami 1376 i 1378. Pierwsza z nich dotyczy zabiegów cesarza o wybór swego syna Wacława na króla rzymskiego. Została ona wciągnięta w drugiej redakcji dzieła za nieznanym źródłem ${ }^{104}$. Krakowski historiograf zrelacjonował z drobnymi potknięciami chronologicznymi i faktograficznymi przebieg elekcji we Frankfurcie oraz koronację Wacława na króla rzymskiego w Akwizgranie. Zaznaczył, że Karol nakłonił elektorów do wyboru swego syna nadaniami i darami, a następnie dodał, iż ta elekcja i koronacja spotkała się z oporem papieża Grzegorza XI i kardynałów, którzy, zdaniem Długosza, ze względu na młody wiek Wacława i brak doświadczenia nie chcieli uznać go za króla rzymskiego ${ }^{105}$. Natomiast pod 1378 r. w drugiej redakcji Roczników dziejopis umieścił najpierw zapiskę o uznaniu przez Karola IV papieża Urbana VI i uzyskaniu od niego zatwierdzenia wyboru Wacława na króla rzymskiego. Wiadomości te zaczerpnął z dzieła De scismate Teodoryka z Nieheim ${ }^{106}$. Natomiast w zakończeniu relacji o 1378 r. w drugiej redakcji Roczników znalazła się nota o śmierci Karola IV wraz ze zwięzłą charakterystyką jego panowania, w której wykorzystano informacje zaczerpnięte z Historia Bohemica Eneasza Sylwiusza Piccolominiego ${ }^{107}$. Długosz przesunął o jeden miesiąc datę dzienną zgonu cesarza, zamiast bowiem 29 listopada podał 30 grudnia. Odnotował przy tym, że Karol został pochowany w katedrze praskiej, oraz poprawnie obliczył lata jego rządów królewskich i cesarskich ${ }^{108}$. W opozycji do syna Wacława, jako następcy na tronie, polski historyk podkreślił, że Karol miłował kler i naukę oraz w rządach zajmował się poważnymi sprawami, a także cechował się odwagą i dążeniem

102 Annales IX, s. 321; Roczniki IX, s. 405.

${ }^{103}$ Annales IX, s. 273, 323; Roczniki IX, s. 346, 408.

104 Biblioteka XX. Czartoryskich, Cod. 1306, S. 939; Annales X, s. 54-55; Roczniki X, s. $72-73$.

${ }^{105}$ Annales X, s. 55; Roczniki X, s. 72-73; F. S e i b t, Karl IV., s. 327-332; J. Š p ě vá č e k, Karel IV, s. 452-465.

${ }^{106}$ Biblioteka XX. Czartoryskich, Cod. 1306, s. 946; Annales X, s. 66; Roczniki X, s. 88; Theoderici de Nyem De scismate, s. 31; K. S t a c h ow s k a, Zapożyczenia Jana Długosza, s. 74-75; J. Š p ě vá č e k, Karel IV, s. 474-479.

107 Biblioteka XX. Czartoryskich, Cod. 1306, s. 949; Annales X, s. 69-70; Roczniki X, s. 93-94; Aeneae Silvii Historia Bohemica, s. 86; S. S o 1 i c k i, Źródła, s. 116.

${ }^{108}$ Annales X, s. 69-70; Roczniki X, s. 93-94; F. S e i b t, Karl IV., s. 398-399; J. Š p ě vá č e k, Karel IV, s. 479-484. 
do wielkich czynów ${ }^{109}$. Dodał jednak, za Eneaszem Sylwiuszem, że cesarz cieszyłby się większą sławą, gdyby nie przedkładał dobra Królestwa Czeskiego nad sprawy cesarstwa i nie doprowadził do elekcji swego syna Wacława na króla rzymskiego przy pomocy pieniędzy - ponieważ każdemu z elektorów obiecał po 100 tysięcy złotych, a gdy nie mógł im spłacić tych sum, zastawił im podatki cesarskie i w ten sposób zrujnował cesarstwo. Elektorzy wykorzystali sytuację i zmusili cesarza do przysięgi, że nie będzie domagał się zwrotu zastawu ${ }^{110}$.

W pierwszej redakcji Roczników Długosz wyraźnie zarysował pozytywny wizerunek Karola IV w zapisach o pojednaniu z biskupem wrocławskim Przecławem z Pogorzeli (pod 1342), ślubie z cesarza z Elżbietą pomorską i kongresie monarchów w Krakowie (pod 1363). Natomiast negatywne i pozytywne cechy Luksemburga nakreślił dziejopisarz w nocie o sprawie księstwa świdnickiego (pod 1346) i obszernej relacji o konflikcie wywołanym obraźliwymi słowami cesarza pod adresem Elżbiety Łokietkówny (pod 1363). Z wyraźną naganą Długosza spotkały się dyplomatyczne zabiegi Karola o przyłączenie diecezji wrocławskiej do metropolii praskiej (pod 1352). Z kolei w drugiej redakcji dzieła krakowski historiograf umieścił noty podkreślające pokojowych charakter Luksemburga, jego roztropną politykę i umiejętność pozyskiwania elektorów oraz wrogów (pod 1346, 1355 i 1376), ale z przyganą spotkało się wyłudzanie darów i podatki od miast włoskich (pod 1355) i przekupywanie elektorów i rujnowanie skarbu (pod 1376).

Przypisane przez polskiego historiografa Karolowi IV cechy dobrego władcy to: roztropność, sprawiedliwość, zaprowadzanie pokoju, odwaga, hojność, naprawianie krzywd wyrządzonych Kościołowi, umiłowanie duchowieństwa, dobre relacje z poddanymi i elitą, umiejętność pozyskiwania nieprzyjaciół, wdzięczność, troska o uniwersytet, gotowość do ustępstw dla zachowania pokoju, zadośćuczynienie za popełnione grzechy oraz pokora. Przeważały one zdecydowanie nad negatywnymi cechami Luksemburga, tj. gniewem, niegodziwością (związaną z próbą oderwania biskupstwa wrocławskiego od metropolii gnieźnieńskiej z krzywdą dla Kościoła polskiego), wyłudzaniem darów, stosowaniem przekupstwa wobec elektorów, rujnowaniem skarbu dla celów dynastycznych i słownym obrażaniem Elżbiety Łokietkówny, matki króla węgierskiego Ludwika Wielkiego. Z Roczników wyłania się więc generalny wizerunek Karola IV jako władcy z wieloma cechami wzorowego monarchy chrześcijańskiego w kontekście ideałów moralnych w późnym średniowieczu ${ }^{111}$.

Wizerunki obu Luksemburgów w Rocznikach Długosza są mocno zróżnicowane. Krakowski historiograf charakteryzował postaci Jana i Karola IV oraz ich dokonania z punktu widzenia interesów i racji politycznych Królestwa Polskiego oraz późnośredniowiecznego ideału władcy chrześcijańskiego. Surowo oceniał Jana, szczególnie

${ }_{109}$ Annales X, s. 69-70; Roczniki X, s. 93.

110 Annales X, s. 70; Roczniki X, s. 93; Aeneae Silvii Historia Bohemica s. 86; F. S e i b t, Karl IV., s. 326-331; J. Š p ě vá č e k, Karel IV, s. 446-447.

111 Por. W. B e rg e s, Die Fürstenspiegel, s. 59-128; M. K o c z e r s k a, Mentalność, s. 119-123; S. S w i ė a w s k i, U źródeł nowożytnej etyki, s. 211-219; R. A n t o n ín, Ideální panovník, s. 291-442; E. S c h l o th e u b e r, Drugi Salomon i „mądry król”. „Teologia władzy" i praktyka władania cesarza Karola IV (zm. 1378), Zeszyty Naukowe Uniwersytetu Jagiellońskiego. Prace Historyczne 141, 2014, z. 3, s. 619-639. 
jego politykę wobec Polski, śląskich Piastów i biskupstwa wrocławskiego, podkreślając przy tym negatywne cechy charakteru Luksemburga, w tym chciwość, niegodziwość, okrucieństwo, rozrzutność, prześladowanie Kościoła i duchowieństwa, pychę i pogardę wobec możnych i szlachty czeskiej oraz forowanie Niemców. Natomiast Karola w pewien sposób przeciwstawiał ojcu, ukazując w bardziej pozytywnym świetle jego osobę i dokonania. Podkreślał szczególnie roztropność w polityce, wytrwałe dążenie do zaprowadzenia pokoju w świecie chrześcijańskim, troskę o Kościół, duchownych i uniwersytet. Niewątpliwie na takiej ocenie Karola zaważyły jego małżeństwa z krewniaczkami Kazimierza Wielkiego - jego siostrzenicą Anną świdnicką oraz wnuczką Elżbietą pomorską. Nie stronił jednak polski dziejopisarz od krytyki niektórych działań politycznych i dynastycznych Karola IV. Z takiej perspektywy prezentował między innymi sprawę biskupstwa wrocławskiego, konflikt wywołany obrazą Elżbiety Łokietkówny przez Karola czy też jego zabiegi o elekcję Wacława IV na tron rzymski w 1376 r. Poglądy Jana Długosza o obu Luksemburgach i ich rządach poważnie oddziaływały z kolei na późniejszą historiografię polską aż do XX w.

\section{BIBLIOGRAFIA}

Antonín R., Ideální panovník českého středověku. Kulturně-historická skica $\mathrm{z}$ dějin středověkého myšlení, Praha 2013.

Berges W., Die Fürstenspiegel des hohen und späten Mittelalters, Leipzig 1938.

Biedrowska-Ochmańska K., Ochmański J., Władysław Jagiełło w opiniach swoich współczesnych. Próba charakterystyki jego osobowości, Poznań 1987.

Bláhová M., Čty̌ri ženy Karla IV, w: Lucemburkové. Česká koruna uprostřed Evropy, Praha 2012.

Bláhová M., Přibíka Pulkavy z Radenína Kronika česká, w: Kroniky doby Karla IV, Praha 1987.

Bobková L., Jan Lucemburský. Otec slavného syna, Praha 2018.

Bobková L., Velké dějiny zemí Koruny české, t. IVa, Praha-Litomyšl 2003.

Bobrzyński M., Smolka S., Jan Długosz, jego życie i stanowisko w piśmiennictwie, Kraków 1893.

Budkowa Z., Nanker, w: Polski słownik biograficzny, t. XXII (1977).

Colberg K., Dietrich von Nieheim, w: Lexikon des Mittelaters, t. III, München 2003.

Dąbrowski J., Dzieje polityczne Śląska w latach 1290-1402, w: Historia Śląska od najdawniejszych czasów do roku 1400, t. I, Kraków 1933.

Dą̧browski J., Elżbieta Łokietkówna 1305-1380, wyd. 2, Kraków 2007.

Dominiak W., Jak postrzegano Luksemburgów na ziemiach polskich, w: Jan Lucemburský: kultura, umění a zbožnost na Moravě a ve Slezsku v době vladý prvního Lucemburka, Ostrava 2012.

Dymmel P., Uwagi nad historią tekstu w autografie Annales Jana Długosza, w: Venerabiles, nobiles et honesti. Studia z dziejów społeczeństwa Polski średniowiecznej. Prace ofiarowane Profesorowi Januszowi Bieniakowi w siedemdziesiątą rocznicę urodzin i czterdziestolecie pracy naukowej, Torun 1997.

Filipek-Misiak A., Karol IV Luksemburski jako ideał władcy w Catalogus abbatum Saganensium, Historie, otazký, problémy 7, 2015, nr 1.

Grodecki R., Kongres krakowski w roku 1364, wyd. 2, Kraków 1995.

Hledíková Z., Arnošt z Pardubic. Arcibiskup, zakladatel, rádce, Praha 2008.

Iwańczak W., Jan Luksemburski. Dzieje burzliwego żywota i bohaterskiej śmierci króla Czech i hrabiego Luksemburga w 21 odsłonach, Warszawa 2012.

Iwańczak W., Polityka Luksemburgów wobec Śląska, w: Silesia - Polonia - Europa. Studia dedykowane Profesorowi Idziemu Panicowi, Katowice - Bielsko-Biała 2019. 
Jurek T., Rodowód Pogorzelów, Kraków 2005.

Jasiński K., Rodowód Piastów śląskich, wyd. 2, Kraków 2007.

Kavka F., Vláda Karla IV. za jeho císařství (1355-1378). Země České koruny, rodová, ř́išská a evropská polityka, t. I-II, Praha 1993.

Koczerska M., Mentalność Jana Długosza w świetle jego twórczości, Studia Źródłoznawcze $15,1970$.

Kornek Z., Wojna o cześć kobiety? Konflikt luksembursko-andegaweński 1361-1364, Studenckie Zeszyty Historyczne Koła Naukowego Historyków Studentów Uniwersytetu Jagiellońskiego 19, 2013.

Krzyżaniakowa J., Eruditio et scientia w Długoszowych wizerunkach władców i biskupów, w: Mente et litteris. O kulturze i społeczeństwie wieków średnich, Poznań 1984.

Krzyżaniakowa J., Portret niedokończony. Kazimierz Jagiellończyk w Annales Jana Długosza, w: Ecclesia, cultura, potestas. Studia z dziejów kultury i społeczeństwa, Kraków 2006.

Kubínová K., Imitatio Romae. Karel IV. a Rím, Praha 2006.

Mandziuk J., Historia Kościoła katolickiego na Śląsku. Średniowiecze, t. 1, cz. 2, Warszawa 2004.

Leuschner J., Dietrich von Nieheim, w: Die deutsche Literatur des Mittelalters. Verfasserlexikon, t. II, Berlin-New York 1980.

Nowacki B., Czeskie roszczenia do korony w Polsce w latach 1290-1335, Poznań 1987.

Ojrzyński R., Obraz Polski i Polaków w pismach Eneasza Sylwiusza Piccolominiego (papieża Piusa II), Warszawa 2014.

Ożóg K., The Concept „rex illiteratus quasi asinus coronatus” in Late Medieval Cracovian Writings, w: Book versus Power. Studies in the Relations between Politics and Culture in Polish History, Frankfurt am Main 2015.

Perzanowski Z., Kanonik krakowski ks. Jan Długosz o królowej Jadwidze, Analecta Cracoviensia $12,1980$.

Petrásek J., České dějiny ve světle strategie vyprávění Annales Jana Długosze, Mediaevalia historica Bohemica 20, 2017, nr 1 .

Potkowski E., Wrocławscy Episcopi Romani u Jana Długosza, w: Lux Romana w Europie Środkowej ze szczególnym uwzględnieniem Śląska, red. A. Barciak, Katowice 2001.

Schlotheuber E., Drugi Salomon i „,mądry król”. „Teologia władzy” i praktyka władania cesarza Karola IV (zm. 1378), Zeszyty Naukowe Uniwersytetu Jagiellońskiego. Prace Historyczne 141, 2014, z. 3.

Schmidt O., Jan z Moravy, patriarcha aquilejský (†1394) a Jan Soběslav, markrabě moravský (†cca 1381). Příspěvek k poznání genealogických vztahů lucemburské sekundogenitury, Časopis Matice moravské 132/1, 2013.

Semkowicz A., Krytyczny rozbiór Dziejów polskich Jana Długosza do roku 1384, Kraków 1887.

Semkowicz-Zarembina W., Powstanie i dzieje autografu Annalium Jana Długosza, Kraków 1952.

Seibt F., Karl IV. Ein Kaiser in Europa 1346-1378, München 1985.

Silnicki T., Dzieje i ustrój Kościoła katolickiego na Śląsku do końca w. XIV, wyd. 2, Warszawa 1953.

Skomiał J., Jan Długosz o Władysławie II Jagielle (Charakterystyka króla w świetle „Annales seu Cronicae incliti Regani Poloniae"), Acta Universitatis Lodziensis. Folia Iuridica 61, 1994.

Skomiał J., Polski portret litewskiego władcy. Witold Kiejstutowicz w świetle Annales Jana Długosza, w: „Rodzinna Europa”. Europejska myśl polityczno-prawna u progu XXI wieku, Wrocław 2015.

Solicki S., Źródła Jana Długosza do problematyki czeskiej, Wrocław 1973.

Stachowska K., Zapożyczenia Jana Długosza z dzieła Teodoryka z Niem, „De scismate”, Rocznik Biblioteki PAN w Krakowie 4, 1958.

Soszyński J., Dzieje starożytne w Fasciculus temporum Wernera Rolevincka, Z Badań nad Książką i Księgozbiorami Historycznymi 7-8, 2013-2014. 
Svatoš M., The Studium Generale 1347/48-1419, w: A History of Charles University, Prague 2001.

Swieżawski S., U źródeł nowożytnej etyki. Filozofia moralna w Europie w XV wieku, Kraków 1987.

Szczur S., Krakowski zjazd monarchów w 1364 roku, Roczniki Historyczne 64, 1998.

Szczur S., Zjazd wyszehradzki z 1335 roku, Studia Historyczne 35, 1992.

Szelińska W., Śląsk w piśmiennictwie Jana Długosza, Wrocław 1993.

Szymborski W., Władysław Jagiełło: władca idealny czy święty?, w: Sprawiedliwość: tradycja i współczesność, Kraków 2006.

Špěváček J., Karel IV. Život a dílo (1316-1378), wyd. 2, Praha 1980.

Špěváček J., Král diplomat. Jan Lucemburský 1296-1346, Praha 1982.

Špěváček J., Václav IV. 1361-1419. K předpokladům husitské revoluce, Praha 1986.

Šusta J., Karel IV. Otec a syn 1333-1346, Praha 1946 (České dějiny, t. II, cz. 3).

Šusta J., Karel IV. Za císařskou koronou 1346-1355, Praha 1948 (České dějiny, t. II, cz. 4).

Šusta J., Král cizinec, Praha 1939 (České dějiny, t. II, cz. 2).

Talarowski A., Dzieje w rękach Opatrzności. Elementy historiozofii Jana Długosza i jej uwarunkowania, Roczniki Historyczne 84, 2018.

Talarowski A., Od poganina do króla arcychrześcijańskiego. Wizerunek Władysława Jagiełły w Rocznikach Jana Długosza, Średniowiecze Polskie i Powszechne 9 (13), 2017.

Worm A., Rolevinck Werner, w: Encyclopedia of the Medieval Chronicle, ed. by G. Dunphy, vol. 2, Leiden 2010.

Zarębski I., Stosunki Eneasza Sylwiusza z Polską i Polakami, Kraków 1939.

Zarębski I., Teoderyk de Niem jako źródło do dziejów polskich (uwagi wstępne), w: Mediaevalia. W 50 rocznicę pracy naukowej Jana Dąbrowskiego, Warszawa 1960.

Zdanek M., O źródłach Jana Długosza do dziejów fundacji Uniwersytetu Krakowskiego, w: Jan Długosz (1415-1480). Życie i dzieła, Kraków 2016.

Žůrek V., Korunovace a český korunovační řád Karla IV., w: Lucemburkové. Česká koruna uprostřed Evropy, Praha 2012.

\section{The images of John and Charles IV of Luxemburg in the Annals of Jan Długosz}

\section{Summary}

Jan Długosz in Books IX and X of his Annals devoted much attention to the first Luxemburgs on the Czech throne, John and Charles IV. He described their policy towards the Kingdom of Poland, the Silesian Piasts and the Teutonic Knights, also the internal situation in the Kingdom of Bohemia and the relations of the Luxemburgs with the Holy See, as well as their dynastic connections. On the basis of a detailed analysis of the Annals, the author concluded that the Cracovian historian characterised the figures of John and Charles IV of Luxemburg and their achievements from the standpoint of the interests and political raison d'État of the Kingdom of Poland and the late medieval ideal of a Christian ruler. Długosz harshly assessed John, especially for his policy towards Poland, the Silesian Piasts and the bishopric of Wrocław, stressing the negative traits of Luxemburg's character, imputing him greediness, iniquity, cruelty, profligacy, persecuting the Church and clergy, haughtiness, and contempt for the lords and gentry of Bohemia, as well as favouring Germans. On the other hand, he presented Charles as an opposite of his father, discussing his person and achievements in a more positive light. Among other things, Długosz stressed the prudence, justice, courage, generosity and peaceful attitude of Charles, as well as his good relations with his subjects, care of the clergy, scholars and the university. However, Długosz did not refrain from critical assessment of some of Charles IV's political and dynastic activities. From this perspective he presented, for example, the conflict 
started by insulting Elisabeth, the mother of Louis of Anjou, by Charles IV, or his efforts to have Venceslaus IV elected to the Roman throne in 1376. The portrayal of both Luxemburgs in the Annals is nuanced, but strongly tinged with the personal attitude of Długosz towards Bohemian matters. The Cracovian historian ably utilised information on the Luxemburg from the works of Pulkava, Jan of Czernków, Piotr of Byczyna, Theodoric of Nieheim, Enea Silvio Piccolomini, and Werner Rolewinck, as well as some still unidentified sources, thus creating his own image of both monarchs. 